\title{
PODAŻANIE \\ JÓZEFA KALINOWSKIEGO KU BOGU - WEWNĘTRZNE ZMAGANIA I POWRÓT DO PRAKTYKI SAKRAMENTÓW
}

\section{WPROWADZENIE}

Postacie formatu św. Rafała Kalinowskiego stale inspirują do podejmowania refleksji nad ich życiem, dziełem, spuścizną. Wyzwanie to - w poszczególnych epokach i momentach historycznych - skupia tych, którzy ukazują ich wpływ na bieg zdarzeń w wymiarze dziejów ojczyzny, Kościoła, powszechnych. Święty ten w polskim dziedzictwie narodowym zajmuje miejsce szczególne. Nie wzrastał i nie dojrzewał wewnętrznie w oderwaniu od ówczesnych uwarunkowań. Podejmując zatem rozważania o tej wyjątkowej postaci, należy mieć na uwadze splot wydarzeń historycznych, w których dane mu było uczestniczyć. W ramach zakreślonych tytułem tekstu interesować nas będą jednak tylko te wątki jego niezwykle bogatej biografii, które są wyrazem podążania młodego Józefa ku Bogu, do pełnej relacji z Nim. Wydaje się, że tak należy patrzeć na proces jego wewnętrznego dojrzewania: jako konsekwentne, acz rozłożone w czasie budowanie żywej więzi ze Stwórcą. Z tych racji ze znaczną ostrożnością trzeba podejść do opinii wskazujących na jego „kryzys religijny” ${ }^{1}$, „kryzys wiary”,

1 Cz. Gis, O. Rafat Kalinowski, Kraków 1979, s. 22; tenże, Ojciec Rafał Kalinowski (1835-1907), Kraków 1984, s. 33. Za przyczynę „kryzysu religijnego" Kalinowskiego Czesław Gil przyjął głównie wpływ środowiska Petersburga, w którym modny stał się indyferentyzm religijny. Przyznaje jednak, że ów kryzys nie spowodował u Józefa „zaniku zainteresowań sprawami wiary, Kościoła, celem życia". Wskazuje na intelektualne poszukiwania młodego Kalinowskiego, przyznaje także, że w okresie petersburskim „nie zagubił się całkowicie”. Cz. GiL, Ojciec Rafat Kalinowski (1835-1907), s. 2; por. S. ADAmCzyк, Niespokojne serce, oprac. Cz. Gil, Kraków 1983, s. 33. Sykstus Adamczyk zaznaczył, że lata studiów Kalinowskiego uznać trzeba za czas „na rozstaju dróg”. Tamże, s. 22. Również zwraca uwagę na wpływ środowiska, w którym „spełnianie obowiązków religijnych zaliczano do dobrego tonu", ale wiara oparta była głównie na tradycji, a nie 
"głęboki kryzys wiary”2 czy nawet odejście od Boga ${ }^{3}$. Gdy z uwaga wczytujemy się w pisma samego Świętego, jako najwłaściwsze źródło refleksji, wyraźnie możemy wskazać, że relacja młodego Józefa Kalinowskiego z Bogiem nigdy nie została zanegowana - jedynie osłabła, czego wyrazem stały się trwające aż dekadę zaniedbania w praktyce sakramentalnej. Należy także dostrzec wpływ sprawy narodowej na ostateczne ukształtowanie się jego wnętrza. W powrocie do pełnej relacji ze Stwórcą miała ona niebagatelne znaczenie ${ }^{4}$. W okresie powstania styczniowego Kalinowski stanął przed ogromną próbą. Stał się również uczestnikiem doświadczenia, które nie występuje poza celą więzienną, na co nie wszyscy jego biografowie zwracają uwagę $w$ dostatecznym zakresie. Nie każdy wychodzi z tego zwycięsko, i to niezależnie od czasu historycznego. Cierpienie za ojczyznę musiało dodatkowo motywować jego poszukiwania sensu w tym, co podją i czego konsekwencje trzeba było przyjąć ${ }^{5}$. Przygodność historycznych zaistnień, klęska powstania skłaniały go do odnalezienia w tym wszystkim logiki następstw. W takich sytuacjach niezbędna jest siła, by to, co przychodzi, godnie przyjąć. Tę siłę odnajdywał w Bogu. Stwórca stawał się dla niego coraz bardziej racją ostateczną i to w jej obliczu klęskę przekuwał w sukces, sięgając na wyżyny ducha i podejmując kolejne ważne dzieła. Nie każdemu dane jest $z$ nieszczęść wychodzić zwycięsko. Józefowi Kalinowskiemu było to dane, może nawet za-

na pogłębionym jej rozumieniu, stąd zaczynała tracić na znaczeniu. Tymczasem Józef Kalinowski szukał „,szczerej pobożności”, zatem pogłębionej. Tamże, s. 33. Na „kryzys religijny” młodego Kalinowskiego wskazuje też Stanisław Fudala. Według niego, rozpoczął się on w Hory-Horkach. Słuchacze nie mieli już „bezpośredniego i żywego kontaktu” z rodziną, która jest nieodzowna $\mathrm{w}$ „kształtowaniu żywej wiary”, a wobec miejscowego duchowieństwa pozostawali „w zupełnym odosobnieniu”. Por. S. FudAlA, Ze św. Rafatem Kalinowskim na ścieżkach wiary, nadziei i mitości, Kraków 2007, s. 24. W innym miejscu autor ten okres petersburski Kalinowskiego określa czasem „zagubienia i poszukiwań”. Tamże, s. 30. Wskazuje też, że na pewnym etapie życia „doznał swoistego zagubienia”, „swoistego kryzysu wiary”. S. FuDAla, Religijność Józefa Kalinowskiego na tle religijności XIX-wiecznej, w: Na drodze do świętości. Rafat Kalinowski, powstaniec 1863 i karmelita bosy, red. E. Niebelski, S. Wilk, Lublin 2008, s. 126.

2 S. WILK, „Ojczyzna nie krwi, ale potu potrzebuje”, w: Na drodze do świętości, s. 12.

3 Szczepan T. Praśkiewicz podkreślił: „Otóż, moi drodzy, pokutuje w naszych prowincjach pojęcie, że św. Rafał w swej młodości, w czasie studiów petersburskich stracił wiarę, i potem się nawrócił. Często, także od tego pulpitu, słyszałem wypowiedzi kaznodziejów mówiące o tym, co gorzejstwierdzenia podobne można te ̇̇ wyczytać w publikacjach naszych autorów, a nie jest to prawdą. Św. Rafał - jak wykazało to szczegółowe badanie jego życia podczas procesu kanonizacyjnego - swej wiary nigdy nie stracił! Tam, w Sankt Petersburgu, wyzuty ze swojego wileńskiego środowiska, obracając się w [...] klimacie Rosji Carskiej, to prawda, zagubił się, zaniechał praktyk religijnych, ale wiary nie utracił. Przeciwnie, chciał ją umocnić, pogłębić, czytał”. Sz.T. Praśkiewicz, Kazanie wygloszone w 2016 roku w Czernej (archiwum prywatne autora).

4 Por. S. Fuddala, Religijność Józefa Kalinowskiego na tle religijności XIX-wiecznej, s. 132.

5 Stanisław Fudala zaznaczył: „Poprzez udział w powstaniu Józef dał dowód prawdziwej miłości do ojczyzny, a poprzez świadome przyznanie się do winy i gotowość ofiary za innych - całkowicie wypełnił przykazanie miłości bliźniego i dał świadectwo chrześcijańskiej wiary. Wydarzenia, w których uczestniczył, odegrały bardzo ważną rolę w procesie chrześcijańskiego dojrzewania do pełni w Chrystusie". S. FuDAlA, Ze św. Rafatem Kalinowskim na ścieżkach wiary, nadziei i mitości, s. $42-43$. 
dane. Jeżeli pozostajemy otwarci na Boże plany, musimy w tym odczytać wyraz łaski Boga, poprzez którą otrzymuje człowiek ważne zadania do podjęcia.

\section{I. ŻYCIE RELIGIJNE PODCZAS NAUKI I STUDIów}

Józef Kalinowski z rodzinnego domu wyniósł wartości, które przekazywały normalne polskie rodziny: przywiązanie do polskiego dziedzictwa, katolicyzmu, odpowiedzialności obywatelskiej, uczciwości ${ }^{6}$. Urodził się w okresie drastycznego ograniczania polskości w życiu publicznym. Treści narodowe rozlewały się zatem w nurcie niejawnym. Pomimo ciężkich represji po powstaniu listopadowym i kolejnych aresztowań jego rodzinne Wilno pozostawało miastem o nastrojach patriotycznych. W wieku ośmiu lat Józef rozpoczął naukę w Instytucie Szlacheckim, usytuowanym w obiekcie poklasztornym dominikanów. Językiem wykładowym był rosyjski, ale lekcje religii prowadzono w języku polskim. W tym okresie uczyło jej dwóch katechetów: o. Mokrzycki, dominikanin, i ks. Jakubowski. O obydwu Kalinowski wypowiadał się z szacunkiem. Podkreślał, że prowadzili lekcje starannie, ks. Jakubowski umiał „pozyskać serce młodzieży"? Przed świętami Bożego Narodzenia i wielkanocnymi uczniowie uczestniczyli w rekolekcjach. Trwały one kilka dni i również były przygotowywane $\mathrm{z}$,wielką ścisłością i wzorowym porządkiem”. Podczas nich uczniów obowiązywało milczenie, a spowiadali się w kościele pw. Świętego Ducha (dominikanów). Uczestniczyli też w procesji Bożego Ciała, która „ciągnęła przez główniejsze ulice miasta”, a jej urok oddziaływał nie tylko na jej uczestników. Po latach Józef przyznał, że pod względem „religijnym nic nam nie brakowało”, ale zaraz dodał: „chyba tylko naszej dobrej woli”. Należy jednak pamiętać, że chłopcy byli jeszcze w takim wieku, że trudno byłoby od nich oczekiwać pełnego rygoru ducha. Na niedziele mały Józef był zabierany do rodzinnego domu. Nie ma żadnych przesłanek, aby w okresie nauki Kalinowskiego w wileńskim Instytucie Szlacheckim jego wychowanie religijne, formacyjne było w czymkolwiek narażone na szwank.

Po ukończeniu Instytutu rodzina, głównie ojciec, oraz sam Józef stanęli przed decyzją, co dalej począć z abiturientem, który świetnie zdawał egzaminy, z nagrodą przechodził do wyższej klasy. Ojciec zdecydował, że najlepszym rozwiązaniem będzie skierowanie obu synów, starszego Wiktora i młodszego Józefa, do Instytutu Agronomicznego w miasteczku Hory-Horki niedaleko Orszy (gubernia mohylewska). Z lektury Wspomnień Kalinowskiego wynika, że już wtedy rozważał myśl

6 „Rodzice chłopca znani byli w środowisku wileńskim ze swego przywiązania do polskości oraz z pobożności i stałości w wierze”. M. GuLGowski, Jestem własnościa innych. Święty Rafat Kalinowski 1835-1907, Kraków 1990, s. 9. Na religijną atmosferę domu Kalinowskich zwraca też uwagę S. ADAmCzYK, Niespokojne serce, s. 11-12.

7 J. Kalinowski, Wspommienia 1835-1877, wyd. R. Bender, Lublin 1965, s. 10.

8 Tamże, s. 12. 
wstąpienia do seminarium duchownego w Wilnie. Dlaczego nie podjął tej decyzji? Winą obarczał samego siebie, a ściślej „młodociane lata”, brak jednoznacznego odczytania wewnętrznego głosu. Wydaje się też nie bez znaczenia fakt, że chciał pozostać lojalny wobec woli ojca. Ważne były również więzi braterskie z Wiktorem, dzielenie ciężarów dalszej wspólnej edukacji. Po latach, już jako zakonnik, dostrzegł skutki braku zdecydowania i niepodjęcia nauki w wileńskim seminarium duchownym. Stwierdził wówczas: „Iżem tego nie uczynił, znaczna część życia, a głównie lata młodego wieku połamały się na nieskładne części, stały się bez pożytku dla mnie i dla bliźnich i w marność się obróciły". Wydaje się, że ocenę tę uznać należy za zbyt surową. W żadnym okresie swojego życia Józef Kalinowski nie zszedł z prawej ścieżki, nigdy nie zagłuszył subtelności i wrażliwości swojego ducha, otwartości na drugiego człowieka, nie porzucił wewnętrznych poszukiwań czy zasad etycznych.

W Hory-Horkach bracia Kalinowscy mieszkali na stancji, u okolicznych mieszczan lub włościan. Przy Instytucie był internat, ale o warunkach, jakie w nim były, Kalinowski wypowiadał się chłodno. W prowadzonej tam pracy wychowawczej dostrzegał ,wiele ujemnych stron”. W Instytucie nauki pobierała głównie młodzież polska, Rosjan nie było, „lecz synów księży schizmatyckich co niemiara” ${ }^{10}$. Polscy słuchacze starali się zachować „jedność i dobre obyczaje”. To okazywało się jednak niewystarczające. W pobliżu wprawdzie był kościół, prowadzono zajęcia z religii, ale „brakło wpływu bezpośredniego i w życiu codziennym zostawaliśmy w zupełnym odosobnieniu od duchowieństwa" ${ }^{11}$. Zabrakło też osób świeckich, które by pociągały młodzieńców swoim przykładem. W takich warunkach, przy braku zorganizowanego życia religijnego, „praktyki pobożne nie bardzo dawały się zachowywać”, a to nie mogło nie oddziaływać na „pojedyncze jednostki”. Ten znak czasu najwyraźniej zaczął dotykać młodego Józefa. W drugim roku nauki ze strony władz Instytutu pojawiły się czytelne zachęty, aby słuchacze brali udział w „zabawach”. Kalinowski po latach przyznał, że uczestniczył jedynie w trzech, w tym podczas wyjazdu do Orszy. Trudno zatem zgodzić się z tymi stanowiskami, które eksponują ten okres jego życia jako czas odejścia od wiary ${ }^{12}$.

Nauka w Hory-Horkach trwała cztery lata, dwa pierwsze sprowadzały się do teorii, kolejne do praktycznego wprowadzania nabytej wiedzy w gospodarstwach. Kalinowski uznał, że do tego rodzaju zajęć nie jest przygotowany i nie podoła im. Wówczas zrodziła się myśl, aby kontynuować naukę w Petersburgu, w Szkole Dróg i Mostów. $Z$ braku miejsc nie został do niej przyjęty, skierował więc kroki do Szkoły Inżynierii Wojskowej. Po półrocznym kursie przygotowawczym stał się słuchaczem drugiej

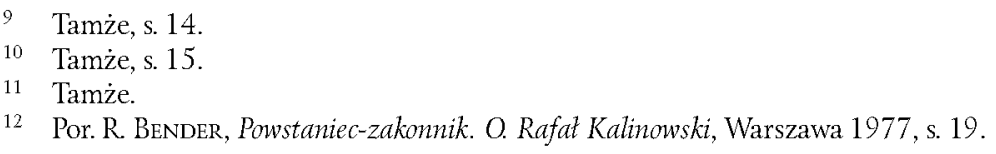


klasy. Po latach decyzję o opuszczeniu Instytutu Agronomicznego w Hory-Horkach i przeniesieniu się do Petersburga nazwie przejściem z „deszczu pod rynnę"13.

Zwracał uwagę, że do stolicy państwa carów przyjeżdżało wielu Polaków, by kształcić się, studiować. Było to z pewnością rzeczą naturalną. Po ukończeniu nauk można przecież było pozostać w kręgach polskich i pracować „na korzyść własnego kraju". Jednak wielu - dla kariery, wygodnego życia - zrywało z polskością, oddając się na służbę zaborcy, wchodząc w związki małżeńskie z Rosjankami. Takie decyzje nieuchronnie prowadziły do czynienia $z$,obczyzny ojczyznę dla siebie i swoich"14. W ten sposób Petersburg „pochłaniał ku własnemu pożytkowi najbardziej wydatne jednostki narodowości polskiej”. Proces ten bardzo niepokoił młodego Kalinowskiego. Warto zauważyć, że od czasów nauki w Instytucie Szlacheckim odwoływał się do tradycji katolickiego Kościoła wschodniego. Jednoznacznie negatywnie oceniał postawę ks. Józefa Siemaszki, likwidatora Unii na ziemiach zabranych, z sympatią wspominał włościan z okolic Orszy, wcześniej unitów, podobnie mieszkańców powiatów: nowogródzkiego, słuckiego, lidzkiego ${ }^{15}$. Zauważał, że w latach 1852-1862 lud w wielu miejscach „zachowywał mocno przywiązanie do wiary. Lecz pokolenie starsze wymierało, a młodsze kształtowało się już pod ścisłym rządowym nadzorem w dziedzinie religijnej"16. Za wielki cios dla katolicyzmu i polskości uważał kasaty klasztorów, zarówno bazylianów, jak i łacińskich.

Po latach Józef Kalinowski wspominał, że nauki na kursie przygotowawczym (do Szkoły Inżynierii Wojskowej) prowadzone były „starannie”. W planach zajęć był również wykład religii ( „katechizmu”). Powierzono go o. Nowickiemu, dominikaninowi z kościoła pw. św. Katarzyny. Kapłan ów na zajęcia przychodził jednak „niezbyt często”, ściślej - „kiedy niekiedy”. Był w podeszłym wieku, ale czy można to uznać za usprawiedliwienie? Religii nauczał również o. Stankiewicz, także dominikanin. Dlaczego nie uzupełniali się w tych obowiązkach? Dlaczego nie podjęli wyzwania, które było nie tylko „legalne”, ale i konieczne? Kalinowski egzamin z religii zdawał przed komisją, w której zasiadał o. Stankiewicz. Zapytał go: „Czy nienależący do Kościoła świętego mogą być zbawieni?”. Po latach Józef przyznał, że poczuł się niepewnie, nie mając wizji klarownej odpowiedzi. Nie wskazuje to na brak wiedzy, raczej na zaskoczenie. Egzaminator, widząc jego zakłopotanie, sam „tę zagadkę rozwiązał, lecz jak się wywiązał, nic nie pamiętam" ". Można domniemywać, że pytanie rzeczywiście mogło skonfundować młodzieńca, tym bardziej że w komisji egzaminacyjnej zasiadali ,sami schizmatycy, generałowie i oficerowie wyższej rangi” ${ }^{18}$.

13 J. KaLINOWsKI, Wspomnienia 1835-1877, s. 18.

14 Tamże, s. 19.

15 Por. tamże, s. 16, 37.

16 Tamże, s. 38.

17 Tamże, s. 23.

18 Tamże. 
Po zdaniu egzaminów wstępnych dyrektor Szkoły Inżynierii zwrócił się do przyjętych słuchaczy, żeby jeszcze raz rozważyli, czy rzeczywiście intencją ich jest w niej studiować. Józef Kalinowski był bardzo bliski rezygnacji z nauki, bowiem „wszystko wstrętnym i przerażającym się okazywało". Ten stan swojego wnętrza opisywał po długim kursie przygotowawczym, a więc okresie, który pozwalał odczytać atmosferę nowego miejsca. Udzielając dyrektorowi odpowiedzi, że podejmuje studia, czuł ból duszy. Po latach zaznaczy: „czyniłem to $z$ tak wielkim cierpieniem wewnętrznym, jakbym siebie na najcięższą niewolę skazywał" ${ }^{19}$. Niepokoił go, a nawet przerażał sposób traktowania słuchaczy z niższych lat przez kolegów z klas starszych. Wszystko to odbywało się za przyzwoleniem władz szkolnych. Odczytywał te zachowania jako wyraz „jakiejś dzikości”, obcego i niezrozumiałego ducha. Józef był osobą wrażliwą, zbyt wrażliwą i otwartą na drugiego człowieka, jego godność, aby tego rodzaju „stosunki” zaakceptować. Gdy był słuchaczem wyższych klas, postanowił te „dzikie obyczaje łagodzić”. Do kształtowania „łagodnych” postaw zaangażował grupę studiujących Polaków ${ }^{20}$. W mury akademii wnieśli wiele normalności.

Wśród Polaków, z którymi Kalinowski pozostawał w zażyłości, był student o nazwisku Lesiewicz, pochodzący z „Małej Rosji”. Należy zwrócić uwagę na jego relacje $z$ tym słuchaczem, a potem absolwentem. $Z$ zapisu już o. Rafała można domniemywać, że dotyczyło to okresu przedpowstaniowego. Po ukończeniu akademii Lesiewicz „przez czytanie z książek teorii błędnych filozofów wiarę stracit”. Józef to zauważył. Postanowił „go podźwignać, zaopatrując dobrymi książkami”. Przyznaje, że nic „nie wskórał". Przy tym fragmencie Wspomnień należy się zatrzymać. Wobec utraty wiary przez osobę mu bliską Józef nie pozostał obojętny, więcej, uczynił, co było w jego mocy, aby jej pomóc. Takiego zachowania trudno się spodziewać po kimś, kto sam zachwiał się w wierze w Boga lub ją stracif. Ponadto przytoczone wyznanie wskazuje, że sam po tego rodzaju literaturę nie sięgał (innym razem przyzna, że tylko czasami). Władze szkolne nie zabraniały polskim studentom czytać książek w języku polskim, w tym religijnych. Przestrzegano jedynie przed sięganiem po pozycje „gorszące”. Kalinowski we Wspomnieniach stwierdza, że „pod tym względem jednak nie było nic do obawy”. Książki przesyłane z domu i od znajomych były „budujące”. Zatem teza o wpływie na młodego Kalinowskiego prądów oświeceniowych raczej nie jest do utrzymania ${ }^{21}$.

Z podobną ostrożnością należy patrzeć na stwierdzenie, że uległ modzie „na indyferentyzm religijny" inteligencji Petersburga ${ }^{22}$. Zważmy, czy nie należałoby tu raczej uwzględniać postaw duchowieństwa prawosławnego, nieprzygotowanego

19 Tamże, s. 24.

20 Por. J. Kalinowski, W stolicy carów, w: Kartki z ksiegi mojego życia, oprac. Cz. Gill, Kraków 2007, s. 18.

21 Por. S. Fudala, Religijność Józefa Kalinowskiego na tle religijności XIX-wiecznej, s. 126.

22 Por. Cz. Gil, Ojciec Rafat Kalinowski (1835-1907), s. 33. 
na pojawiające się wyzwania. Nauczyciel religii prawosławnej „nie potrafił zyskać serca i poważania u swoich uczniów" ${ }^{23}$. Z tej racji niewielu młodych Rosjan szanowało swoich kapłanów, „swe wyznanie i mało sobie ważyło obrządki cerkiewne”. W jednym z zatargów koleżeńskich został zraniony Polak. Po tym zajściu przez pewien czas polscy studenci w niedziele i święta kierowani byli do kaplicy prawosławnej usytuowanej w akademii, ale bez zmuszania ich do czynnego udziału w liturgii. Mogli wówczas obserwować „niezbyt wydatne oznaki pobożności naszych towarzyszy prawosławnych"24.

Pojawiających się wyzwań duszpasterskich nie odczytywali także duchowni łacińscy. W kolejnych latach wykładowcą religii w Szkole Inżynierii pozostawał o. Stankiewicz. Katechizm przygotował w języku rosyjskim, „co straszny w nas wstręt wzbudzało i chwytaliśmy się zań tylko na kilka dni przed egzaminem"25. Takiego spojrzenia na postawę kapłana nie wypracowuje osoba religijnie obojętna. Świadomi studenci, wśród nich Józef Kalinowski, musieli mieć dość wiedzy religijnej, by rozpoznać charakter podręcznika, do tego stopnia, że budził w nich „wstręt”. Widzieli również, że o. Stankiewicz nie przestrzegał prawa kanonicznego w kwestii małżeństw mieszanych, katolików z prawosławnymi. Zobojętnienie religijne środowiska, w którym przebywał młody Kalinowski, było przez niego wyraźnie dostrzegane. Fakt ten należy uznać zarówno za wyraz jego samodzielności w myśleniu, jak i postawy religijnej.

W okresie petersburskim Józef Kalinowski czytał między innymi Wyznania św. Augustyna, Wieczory petersburskie Josepha de Maistre'a (napisane podczas pobytu służbowego w stolicy Rosji), jednego z twórców myśli konserwatywnej, Geniusz chrześcijaństwa François-René de Chateaubrianda, upominającego się o budowę porządku społecznego opartego na treściach ewangelicznych. Lektury te musiały rozszerzać horyzonty myślowe czytającego, otwierać go na przestrzeń sacrum. Studenci z kręgu Kalinowskiego - a zatem i on - uczęszczali na Msze św. do kościoła dominikanów przy Prospekcie Newskim. Kazania były tam głoszone w języku polskim, francuskim i niemieckim, między innymi przez o. Dominika Souillarda ${ }^{26}$. Udział w liturgii jednoznacznie wskazuje, że się modlili, że modlił się Józef Kalinowski. Przestał wprawdzie (od 1853 roku) przystępować do sakramentu pokuty i pojednania, ale nie zerwał relacji z Bogiem - mimo że osłabła, przetrwała.

23 J. KaLINowski, Wspomnienia 1835-1877, s. 24.

24 Tamże.

25 Tamże, s. 29.

26 Por. B.J. KucharsKi, Wędrówka do źródet nadziei. Duchowe przestanie św. Rafała Kalinowskiego dla wspótczesności, Kraków 2007, s. 42. 


\section{WOBEC WYZWAŃ RELIGIJNYCH W OKRESIE PRACY ZAWODOWEJ}

Po ukończeniu studiów w Petersburgu, mając 20 lat, Józef Kalinowski ponownie stanął przed ważną decyzją. Pojawiła się wizja wyjazdu z Wincentym Bortkiewiczem do pracy na Kaukazie. Wkrótce otrzymał też propozycję pracy w charakterze nauczyciela w Szkole Inżynierii. Wielu byłoby zadowolonych z tego rodzaju ofert, Kalinowski czuł jednak niepokój duszy, która upominała się o głębsze poszukiwania. Przyznawał, że w tym czasie „do niczego nie czuł pociągu”. Miał świadomość uzyskanej wiedzy, możliwości podjęcia pracy dającej utrzymanie, nawet kariery zawodowej, a mimo to nie dostrzegał powodów do zadowolenia. „Wiedziałem, że żyję - zapisze - ale do niczego w życiu stateczniem się nie przykładał. Wszystko dla mnie było obce" 27 . W tym poczuciu obcości, braku czytelnie nakreślonej drogi, życiowego wyzwania zadawał pytania o sens życia. Porównywał siebie do „ruchomości”, bardziej w rozumieniu przedmiotu wydarzeń dotykających go aniżeli świadomego ich podmiotu. W tym okresie najchętniej sięgał po kolejne książki. Nie zaznacza, że to one były powodem wewnętrznego napięcia. Interesowały go $z$ reguły pozycje ambitne. Nadal z upodobaniem czytał prace Josepha de Maistre'a, powracał do św. Augustyna. W duszy czuł „wewnętrzny popęd” ku większej otwartości na obecność Boga. Zaznaczy wprost, że coraz mocniej „budził” się ku Stwórcy, „tu i ówdzie mocno”, choć jeszcze „przechodnio”. Pomimo to praktyki kościelne wciąż zaniedbywał. Gdy przejeżdżał obok kościoła pw. św. Stanisława, pojawiła się myśl, aby zatrzymać się i wejść do świątyni. Poczuł niepowtarzalny klimat tego miejsca (określi je doznaniem). Ukląkł przy konfesjonale $z$ intencją wyspowiadania się - „Na nieszczęście był pusty”. Nikogo też nie było w kościele i wówczas Józefa „płacz [...] niezrozumiały ogarnął. Tęsknota jakaś pochłaniała całą istotę"28.

To przeżycie na trwałe zapisało się w świadomości przyszłego świętego. Coraz usilniej szukał „punktu oparcia się”, ciągle jeszcze nie umiejąc go odnaleźć. Ten stan duszy określał mianem „,chwiejności”. Wydaje się, że był wobec siebie zbyt surowy, przecież coraz bardziej odczytywał swoje wewnętrzne potrzeby, stale poszukiwał, konsekwentnie dążył do pełniejszego rozumienia otaczającego świata i swojego w nim miejsca. Nie należał do osób, które oddawały się „pogoni” za towarzystwem. Owszem, uczestniczył w wielu spotkaniach, ale raczej go one męczyły. Czy świadomie szukał samotności i czy uznawał ją za wyraz cierpienia? W liście do Masi Kalinowskiej zaznaczy, że samotność jest „przyjemnością mądrych”, pozwala bowiem na „szukanie ducha" 29 . W pewnym zakresie to poczucie wyobcowania tłumaczyć należy faktem pozostawania poza rodzinnym krajem. Zaznaczył, „żeśmy wszyscy wyglądali

27 J. KalinowskI, Wspomnienia 1835-1877, s. 34.

28 Tamże.

29 List do Masi Kalinowskiej, styczeń 1859, w: J. Kalinowski, Listy 1856-1872, wyd. Cz. Gil, t. I, cz. I (1856-1872), Lublin 1978, s. 56. 
na obczyźnie jak rośliny przesadzone z rodzimego gruntu na grunt obcy”. Taka roślina skazana jest zwiędnięcie albo zostanie przez inne „przytłumiona”. Męczyła go myśl, że swoje siły twórcze nie dla własnego kraju poświęca, a obcego.

Obok powinności wobec ziemskiej ojczyzny zauważał potrzebę podjęcia zadań na drodze pielgrzymowania „do żywota wiecznego”. Z całą ostrością sformułował pytanie: „Będąc synami Kościoła Świętego, gdzie synostwo nasze było? ”30. Myśli swoje kierował zatem ku podstawowym pytaniom egzystencjalnym. Czuł się synem Polski, a równocześnie synem Kościoła. Coraz silniej zarysowywała się linia powinności wobec obu tych przestrzeni. Podczas świąt katolickich zachowywał, wraz ze znajomymi, „dawne zwyczaje ojczyste”, z całą „serdecznością i prostotą, bez przymusu lub zbytku". Uczestniczył w spotkaniach towarzyskich, podczas których rozprawiano także o sprawach polskich. Przyznawał jednak, że pozostawał podczas nich bardziej słuchaczem aniżeli czynnym uczestnikiem. Dręczyło go, że ciagle zbyt mało wiedzy posiadał o dziejach ojczystych, pomimo lektury książek historycznych i poświęconych literaturze polskiej.

Gdy tylko pojawiała się sposobność, Kalinowski chętnie odwiedzał krewnych i znajomych. Pewnego razu w Studzionkach niedaleko Nieświeża spotkał bernardyna, który kwestował po odprawieniu Mszy św. Gdy zobaczył Józefa w mundurze carskim, „przystąpił śmiało z wesoła postawą”, a ten, nie mając przy sobie pieniędzy, powiedział, że w „miejsce ofiary pieniężnej osobą własną Kościołowi służyć będzie”. Reakcja bernardyna była natychmiastowa: „Chwytam cię za słowo [...] pamiętaj wykonać, co przyrzekasz" ${ }^{31}$. Wydaje się, że tę odpowiedź Józefa uznać trzeba za coraz silniejszy głos poszukującego wnętrza ${ }^{32}$.

W Petersburgu pracował przez półtora roku. Gdy zaproponowano mu zatrudnienie przy wytyczaniu linii kolejowej Kursk-Kijów-Odessa, przyją ofertę. Wiosną 1859 roku opuścił stolicę carów i wyruszył w stronę Kurska. Z uwagi na charakter pracy przebywał poza większymi ośrodkami, wśród ludu. Wówczas to otrzymał książeczkę do nabożeństwa od Polaka, który wykonywał rysunki. „Czytanie tej książki - podkreślił po latach - niezmiernie na duszę oddziaływało, szczególniej budziło się uczucie ufności w pośrednictwo Matki Najświętszej”33. Przy tekście Pozdrowienia anielskiego znalazł uwagę, że w chwilach trudnych należy je odmawiać $\mathrm{z}$,gorącością ducha”. I rzeczywiście, w niedługim czasie znalazł się „w największym niebezpieczeństwie utraty życia" (we Wspomnieniach nie podaje żadnych szczegółów). Zaczął się modlić. Gdy zagrożenie minęło, przyjął, że uratowało go wstawiennictwo Matki

30 J. Kalinowski, Wspomnienia $1835-1877$, s. 35 .

31 Tamże, s. 38.

32 Na ten fakt zwraca uwagę Stanisław Fudala, przyjmując go za jedno z najważniejszych wydarzeń przesądzających o późniejszym losie Józefa Kalinowskiego. Por. S. Fudala, Religijność Józefa Kalinowskiego na tle religijności XIX-wiecznej, s. 131.

33 J. Kalinowski, Wspommienia $1835-1877$, s. 55. 
Bożej ${ }^{34}$. Zaczął rozważać, ,jaką potężną bronią jest modlitwa. Jak wszechmocnym wstawiennictwo Najśw. Panny. Jak zbawienne ku dobru naszemu środki podaje Kościół św. przez nabożne książki, z których prawda Boża się przebija" ${ }^{35}$.

Jeżeli stajemy się otwarci na obecność Boga, z coraz większą siłą uświadamiamy sobie, że łaska Boża wpływa na los człowieka. Czy zatem spotkanie z rysownikiem nie było wyrazem tej łaski? Nie pozostało ono faktem bez znaczenia w życiu Kalinowskiego. Czy u człowieka pogrążonego w kryzysie wiary powstaje przekonanie o wstawiennictwie Maryi? Wskazuje to raczej na wyraz zaufania, zawierzenia ${ }^{36}$. Trzeba go wpisać w ówczesne zbliżanie się Józefa ku Stwórcy ${ }^{37}$. Pozostając na olbrzymich bezdrożach, często sam, dużo czytał, rozmyślał. Napisał wówczas do brata Wiktora, że

przy ciągłej samotności wyrobić w sobie umiałem życie wewnętrzne i powiem Wam szczerze, że ta ciągła praca ze sobą i nad sobą daleko od ludzi, wielką zmianę ku dobremu we mnie zrobiła. Poznałem cały ogrom potrzeby utrwalonych pojęć religijnych i ostatecznie ku nim się zwróciłem ${ }^{38}$.

Swój wpływ ponownie wywarły Wyznania św. Augustyna ${ }^{39}$.

Przed zimą powrócił do Petersburga i pracował w biurze projektowym. W październiku 1860 roku, na własną prośbę, został skierowany do Brześcia Litewskiego, by nadzorować budowę fortecy ${ }^{40}$. Życie w Brześciu toczyło się monotonnie. Kalinowski nadal dużo czytał, pod koniec 1961 roku założył szkółkę niedzielną dla młodych rzemieślników i prowadził w niej zajęcia. W tym czasie przyjął też na wychowanie kilkunastoletniego półsierotę. Wszystko to są czytelne znaki otwartości na drugiego człowieka.

34 O tym zawierzeniu i o maryjnej duchowości Kalinowskiego zob.: Sz.T. Praśkiewıcz, Z Maryją zawsze $i$ we wszystkim, Kraków 2007; tenże, „Maryja zawsze $i$ we wszystkim”. Duchowość maryjna św. Rafała Kalinowskiego, Kraków 1999; J. DĄBRowsKi, Maryjność šw. Rafała Kalinowskiego, Kraków 2001.

35 J. KalinowsK, Wspomnienia 1835-1877, s. 55.

36 Sz.T. Praśriewicz, W cieniu Ostrej Bramy. Życie Świętego Rafata Kalinowskiego, Wilno 1991, s. 6.

37 Sykstus Adamczyk zaznacza, że książka do nabożeństwa stała się ważnym krokiem do „odrodzenia”, ale zaraz zadaje pytanie: „Czy ten zwrot dokonał się w życiu Józefa nagle, bez głębszego przygotowania?”, i odpowiada: „Nie! To był proces, który zaczął się dużo wcześniej, a będzie trwał przez całe życie. Bo przecież życie człowieka jest drogą do Ojca". S. AdamczyK, Niespokojne serce, s. 42.

38 List do Masi i Wiktora Kalinowskich, 25 września 1859, w: J. Kalinowski, Listy, t. I, cz. I, s. 66.

39 Por. I. Adamska, Biorę życie takim jakim ono jest (Rzecz o św. Rafale Kalinowskim), Warszawa 1998, s. 6; Święty Rafat Kalinowski. Życie. Proces. Cud kanonizacyjny. Modlitwy, oprac. M. Maziarz, Kraków 2010, s. 10; Cz. GIL, Duchowość bt. Rafata Kalinowskiego, w: W bliskości Boga. Modlitwa dziś. Święci polscy naszych czasów, oprac. S. Olejnik, Kraków 1986, s. 210.

40 Por. R. Bruderhorer, Pater Raphael Kalinowski. Wegbegleiter zu Gott. Von Sibirien In den Karmel, Wien 1991, s. 13-14. 


\section{WPEYW POWSTANiA NA STAN DUCHA RELIGIJNEGo}

Józef Kalinowski nie był zwolennikiem ani manifestacji patriotyczno-religijnych $z$ lat 1861-1862 $2^{41}$, ani wzniecenia powstania w styczniu 1863 roku. Sledził ówczesny bieg zdarzeń, przeżył śmierć manifestantów 27 lutego 1861 roku. Wychodził z założenia, że siły polskie są niewspółmiernie słabe wobec rosyjskiej „potęgi rządu”, mającego do dyspozycji silną armię. Proporcje te wywoływały „przed wzrokiem duszy sprzeczność bezbronnego narodu" 22 . W liście do brata Wiktora wskazywał, że ojczyzna „nie krwi, której do zbytku się przelało na niwach Polski - ale potu ona potrzebuje!”, i zaraz dodawał, że „na nieszczęście kraju, młodzież tego rozumieć nie chce" ${ }^{43}$. O sens i szanse zrywów narodowych spierali się ich uczestnicy, a potem kolejne pokolenia. I choć klęski staramy się przekuwać w czynniki kształtujące naszą tożsamość narodową, to nie możemy nie zauważać skali represji popowstaniowych. Kalinowski obserwował przygotowania do powstania, pierwsze walki i gdy widział więcej entuzjazmu aniżeli możliwości, ogarniało go przygnębienie. Mając przygotowanie wojskowe, w całej ostrości dostrzegał brak właściwej organizacji. Znał té̇ zdecydowanie strony rosyjskiej, rozumiał, że rząd skieruje przeciwko powstańcom na tyle znaczące siły, aby ich zupełnie rozbić. Równocześnie analizował informacje przychodzące z różnych stron Królestwa i Litwy. Szczególne wrażenie wywierała na nim skala zaangażowania w walki powstańcze na Litwie. „Stawiłem przed oczy swe to wszystko - napisze po latach - i zadawałem sobie pytanie, czy wolno mi wobec tych tylu osób, które dla sprawy, uważanej już wówczas za istotnie narodową, wszystko poświęcili, czy wolno mi pozostawać bezczynnym" 44 .

Powstanie „żadnego powodzenia nie wróżyło”, po rozbiciu oddziałów na Żmudzi całe wsie wywożono na Sybir. Tę sytuację określał Kalinowski jako „prawdziwe całopalenie". Zbiorowy imperatyw powstawania narodu z kolan był jednak na tyle silny, że wielu wybierało walkę. Widział to Kalinowski i głos wnętrza wskazywał, że nie $z$ rozsądku, a z obowiązku nie może pozostać obojętny, że i on musi się poświęcić $^{45}$. W Brześciu zetknął się z powstańcami wziętymi do niewoli. Był świadkiem

41 W Brześciu Litewskim i okolicach manifestacje patriotyczne nie były organizowane, z uwagi na postawę duchownych nie odprawiono także Mszy św. w intencji ojczyzny. Por. Cz. GiL, $O$. Rafat Kalinowski 1835-1907, w: O. Rafat Kalinowski, karmelita bosy 1835-1907, oprac. Cz. Gil, Kraków 1983, s. 27; S. ADAmCzyK, Niespokojne serce, s. 48.

42 J. KaLInowsKa, Wspomnienia $1835-1877$, s. 61.

43 List do Wiktora Kalinowskiego, 17 marca 1863, w: J. KaLInowsKI, Listy, t. I, cz. I, s. 102.

44 J. Kalinowski, Wspomnienia 1835-1877, s. 67.

45 Ks. abp Karol Wojtyła tę decyzję Józefa Kalinowskiego skonstatował następująco: „Wiedział, że powstanie ma ciężkie zadanie, że jest sprawą przegraną, a jednak uważał sobie za swój święty obowiązek, ażeby do tego trudnego zadania przyłożyć rękę". K. WOJTYŁA, Cztowiek oddany Bogu. Kazanie wygtoszone 15 listopada 1966 r.w Czernej przy grobie Stugi Bożego Rafała Kalinowskiego, w: Oddat życie z milości. Rafat Kalinowski - Swięty z Miasta Papieskiego w wypowiedziach Stugi Bożego Jana Pawła II, Wadowice 2007, s. 11. Przeciwnikiem powstania był Jakub Gieysztor, jeden z późniejszych jego przywódców. „Wieść ta - zapisze - raziła mnie jak grom. Ani przedtem, ani potem, 
prowadzenia jeńców z rozbitego oddziału Romana Rogińskiego ${ }^{46}$. Spotkania z nimi musiały być „bolesne”, wywołujące „skurcz serca” "47. Tylko przypadek sprawił, że nie wziął udziału w wyprawie przeciwko powstańcom. Taki bieg wydarzeń, wewnętrzne przeżycia przesądziły o podjęciu ostatecznej decyzji. Czy można było w takiej sytuacji pozostawać w mundurze żołnierza rosyjskiego, ,nawet gdy się było przekonanym, że powstanie nie ma żadnych szans powodzenia"? ${ }^{48}$

Kalinowski postanowił prosić o zwolnienie $z$ wojska. Podjął też starania, aby decyzja ta została w miarę szybko wydana. W tym celu w kwietniu 1863 roku pojechał do Petersburga. Interweniował u znajomych. Był oficerem, przyjmował, że obowiązują go regulacje wojskowe. Po otrzymaniu zwolnienia, w maju, natychmiast udał się do Warszawy z zamiarem „zwrócenia się” do rodzinnego Wilna. Naczelnik Wojny Rządu Narodowego wyznaczył go na naczelnika Wydziału Wojny na Litwie. Wkrótce po przyjeździe do Wilna, w czerwcu, był świadkiem stracenia Zygmunta Sierakowskiego. Ukląkł wówczas i modlił się w intencji powstańca ${ }^{49}$.

Sytuacja powstania na Litwie nie napawała optymizmem, zauważalna była niemoc kierownictwa, oddziały pozostawały rozproszone, w znacznej części już rozbite, brakowało koordynacji, dyscypliny, a nawet podstawowych informacji o walczących. Dowódcy oddziałów często działali pojedynczo, bez rozeznania sytuacji, skazując na niepowodzenie podejmowane akcje. Nie miejsce tu jednak na ocenę przebiegu powstania. 31 lipca 1863 roku aresztowany został Jakub Gieysztor, prezes Wydziału Wykonawczego Litwy. Józef Kalinowski otrzymał informację, że zapadł wyrok i że Gieysztor lada dzień zostanie wywieziony w głąb Rosji ( $w$ istocie skazany został dopiero w 1865 roku). „Bardzo to nas bolało i chciałem obdarować go jaką pamiątką, mogącą mu na wygnaniu pociechę przynieśc ${ }^{50}$. W padł na pomysł, aby przekazać mu krzyż z relikwiami, który zauważył u siostry Marii (Maryni). Gdy ją o niego poprosił, usłyszał, że otrzyma, ale pod warunkiem, że się wyspowiada ${ }^{51}$. Warunek

nigdy największe osobiste nieszczęścia takiego wpływu na mnie nie wywarły". Cyt. za: S. ADAMCZYK, Niespokojne serce, s. 50.

Romuald OD św. Eliasza, Wspomnienie pośmiertne o Rafale Kalinowskim karmelicie bosym uczestniku powstania z roku 1863, diugoletnim sybiraku i wygnańcu, Kraków 1908, s. 13.

47 Tamże, s. 54. To spotkanie nim wstrząsnęło. „W nocy Kalinowski chodził półprzytomny po pokoju. Do uszów jego dochodził śpiew pieśni patriotycznych i religijnych powstańców umieszczonych w kazamatach. Nie, nie mógł zasnąć". W. Kluz, Dzien zbawienia. Opowieść o życiu Stugi Bożego Józefa Rafała Kalinowskiego, Kraków 1972, s. 76-77.

48 Cz. Gil, Św. Rafat Kalinowski (Rys biograficzny), w: Święty Rafat Kalinowski. Ksiega Pamiątkowa 1835-1907, Kraków 1993, s. 11.

49 Por. J. Kalinowski, Wspommienia 1835-1877, s. 48.

50 Tamże, s. 80.

51 Okoliczność tę Tadeusz Żychiewicz przedstawił następująco: „Józef, jako krewny, odwiedził go [Gieysztora - E. W.] w więzieniu. Postanowił ofiarować mu cenny krzyżyk z relikwiami, który miała jego czternastoletnia przyrodnia siostra Marynia. A siostrunia podlotek schytrzyła się i rzekła mu tak: Józuś, przestań wreszcie być taki okropnie mądry [ ...]. Idź, Józuś, zwyczajnie do spowiedzi, bo przykro patrzeć na to, co wyrabiasz. Pójdziesz do spowiedzi, to dam krzyżyk". T. ŻYCHIEWICZ, Rafał Kalinowski, Kraków 1984, s. 45; por. S. ADAmczyк, Niespokojne serce, s. 61. 
przyjął, więcej, przyrzekł, że tak postąpi. Wyproszony krzyż z relikwiami przekazał Gieysztorowi. „Po tej umowie musiałem być słownym” - zatem 15 sierpnia, w dniu Wniebowzięcia Najświętszej Maryi Panny, przystąpił do spowiedzi w kościółku pomisjonarskim. Po latach zapisał: „Co się Bogu podobało wykonać w mej duszy w czasie chwil spędzonych u stóp spowiednika w[ielebnego ] o[jca] Eymonta [...] może wypowiedzieć tylko ten, kto podobnych chwil doświadczył" 52 .

Przystąienie do spowiedzi uznał za wyraz woli Boga, za akt o szczególnym znaczeniu w swoim życiu. Odtąd do 25 marca 1864 roku, czyli dnia aresztowania, spowiadał się co tydzień, u ks. Felicjana Antoniewicza. Do Komunii św. przystępował "często" (pamiętajmy, że ówczesna dyscyplina sakramentalna zabraniała czynić tego codziennie). Sakramenty „odradzały ducha i utrzymywały w trzeźwości”, w roztropności myśli i czynów. Wkrótce postanowił, że każdego dnia będzie uczestniczył we Mszy św. Uczęszczał do kościoła pw. św. Elżbiety, który określał mianem „przytułku" dla siebie. Czasami udawał się do kościoła przy byłym klasztorze bonifratrów. W tym czasie snuł rozważania, że ,gdy się czasy uspokoją, a Bóg zachowa mi swobodę", wstąpi do kapucynów w Warszawie. Pełniąc jednak tak istotne obowiązki w rządzie powstańczym na Litwie, musiał się liczyć z tym, że jego zatrzymanie jest kwestią czasu. Długo o jego zaangażowaniu w walkę spośród osób z rodziny wiedziała jedynie Zofia Kalinowska, przybrana matka. Ojciec był przeciwny udziałowi synów (Józefa, Wiktora i Gabriela) w powstaniu.

Po aresztowaniu w nocy z 24 na 25 marca 1864 roku Kalinowski trzymany był w więzieniu, w zamkniętym klasztorze podominikańskim. Warto zatrzymać się nad przyjętym przezeń wówczas porządkiem dnia. Wstawał wcześnie, o godzinie piątej, modlił się, następnie rozmyślał. Po otrzymaniu książeczki do nabożeństwa (Korona Męki Pana Naszego Jezusa Chrystusa), o której zakup prosit, pochylał się nad jej treścią. Okno celi skierowane było w stronę podwórza klasztornego, do którego przylegał kościół pw. Świętego Ducha. To pozwalało mu codziennie słuchać odprawianej tam Mszy św. Przed Wielkanocą mógł się wyspowiadać, przyjąć Komunię św. Po świętach został przeniesiony do innej celi, od strony podwórza, przy bramie wejściowej. Rozkład dnia utrzymywał w podobnym porządku. Przed południem uczył się łaciny. Po obiedzie starał się nie zasypiać, śpiewał Litanię o Najświętszej Pannie, odbywał „gimnastykę pokojową".

Czas spędzony przez Józefa Kalinowskiego w więzieniu uznać należy za szczególny rodzaj doświadczenia. Od pierwszych chwil bardzo czytelnie zapada on w świadomość osadzonego. Ważne jest wówczas zachować spokój wnętrza, równowage ducha, nie załamać się, nie utracić wiary w podjęte wyzwanie ${ }^{53}$. Józef zachowywał się

52 J. KaLINowski, Wspomnienia $1835-1877$, s. 81.

53 „I tak poznał Kalinowski jeden jeszcze gatunek ludzi: funkcjonariuszy rosyjskiej policji politycznej. Byli to naprawdę fachowcy najwyższej klasy z nosem myśliwskiego psa, dużą inteligencją i świetną znajomością praktycznej psychologii; nic żadne prymitywne stupajki. Gdy trzeba- 
godnie, swoją postawą budził powszechny szacunek, a ponadto jego żarliwość religijna kształtowała mu opinię życia w świętości ${ }^{54}$. W drodze na pierwsze przesłuchanie odmówił Pod Twoja obrone. Do niczego się wówczas nie przyznał, podobnie jak podczas kolejnych przesłuchań. Z czasem uświadomił sobie, że jego milczenie poszerzy krąg podejrzanych o osoby z rodziny. Postanowił pełną odpowiedzialność wziąć na siebie. Czynił to ze świadomością, że w takiej sytuacji wyrok może być tylko jeden: kara śmierci ${ }^{55}$. Złożonymi zeznaniami nikogo nie obciążał. Jeżeli o kimś przekazał coś więcej, to był pewien, że ta osoba już nie żyje lub wyemigrowała. Wyrok w jego sprawie zapadł 2 czerwca 1864 roku. $Z$ uwagi na zaliczenie jego działalności powstańczej do pierwszej kategorii przestępstw, został skazany na rozstrzelanie. Otarł się zatem o śmierćs ${ }^{56}$. Rodzi się pytanie, na ile fakt ten pozostawał znakiem w kolejnych jego wyborach ${ }^{57}$.

Z wyrokiem nie mogła pogodzić się rodzina Kalinowskich, która natychmiast podjęła starania o zmianę kary. Początkowo nie przynosiły one rezultatów. Nawet łapówka w wysokości 500 rubli, oferowana komendantowi Wilna, nie była argumentem przesądzającym. Wpłynął on jednak na Murawiewa, aby nie wykonywać wyroku śmierci na młodym Kalinowskim, bo uznany zostanie „za męczennika i świętego" 58 . 2 lipca zmieniono klasyfikację przestępstwa, zaliczonego do kategorii drugiej. Józef pozbawiony został tym samym rangi, szlachectwa, praw stanu i zesłany na katorgę do twierdz Syberii.

nieskazitelnie wychowani, aksamitnie uprzejmi, ogromnie przyjacielscy, szczerze współczujący panu sztabskapitanowi, który się tak niefortunnie zaplątał w brzydką sprawę. Owszem, potrafili być także i brutalni, ale tylko wtedy, gdy było to nieodzowne i mogło być skuteczne [...]. Kalinowski nie przyznawał się do niczego. Więc śledczy inaczej: rozmowa całkiem towarzyska o ojcu, o braciach - gdzie też się podziewają? (a czterech ich było w powstaniu), o krewnych nawet najdalszych, o znajomych. Półsłówka, aluzje, zadumania, dziwne pytańka, nazwiska, które nie powinny były paść, lecz jednak padły". T. ZYCHIEWICZ, Rafat Kalinowski, s. 51-52. Por. tamże, s. 56.

Bartłomiej J. Kucharski niezwykle sugestywnie podkreślił, że Józef Kalinowski został uwięziony „przez władze carskie i skazany na karę śmierci za swoją działalność antyrosyjską. Czy możemy wyobrazić sobie, co przez blisko miesiąc przeżywa jako więzień oczekujący na stracenie w celi śmierci? [...] Wszystko ogarnia mrok oczekiwanej i nieuchronnej śmierci”. B.J. KLicharsKI, Wędrówka do źódeł nadziei, s. 24. Na ten aspekt zwrócił też uwagę ks. abp Karol Wojtyła. Udział w powstaniu uznał za świadectwo wskazujące, ,jak bardzo kochał swoją ziemską ojczyznę, jak bardzo pomagał jej w walce o byt i wolność, jak bardzo był gotów stanąć oko w oko ze śmiercią". K WoJTYモA, Człowiek oddany Bogu. Kazanie wygłoszone 15 listopada 1966 r. w Czernej przy grobie Stugi Bożego Rafała Kalinowskiego, s. 58.

57 Ks. Jerzy Kalinowski, brat Rafała, w świadectwie o nim zaznaczy, że to właśnie podczas uwięzienia „zaczyna w nim kiełkować powołanie”. Dojrzało ono na zesłaniu, postanowił wówczas skonkretyzować zamysł wstąpienia do klasztoru. Por. J. KaLINowski, Józef- rys życia w oczach brata, w: Wychwalajcie mężów stawnych. Wsponmienia o swiętym Rafale Kalinowskim, wybór i oprac. Cz. Gîl, Kraków 2008, s. 45.

58 Tamże, s. 58; J. Kalinowski, Wspomnienia 1835-1877, s. 91; R. Bender, Powstaniec-zakonnik, s. 72 . 
Przez kilka dni, pomiędzy zmianą wyroku a deportacją, wraz z innymi skazańcami trzymany był w fortecy wileńskiej, Ostrogu. Codziennie uczestniczył we Mszy świętej. Odwiedzili go przybrana matka Zofia, brat Jerzy i siostra Maria. Ojciec, Andrzej Kalinowski, nie spotkał się z synem. Józef nie mógł nie zwrócić na to uwagi. Przyjął ten fakt z głębokim bólem. Przed deportacją poprosił o zdjęcia bliskich, Nowy Testament, Księgę Joba i swój krucyfiks. Dokładnie zapamiętał okoliczności wyprowadzenia skazanych na dworzec kolejowy. Po latach zapisał:

Skazanych liczba była olbrzymia; a któryż to już pochód od czasu zaczęcia ruchu powstańczego? Nie było stanu i wieku, który by nie miał swych przedstawicieli: obywatele ziemscy, lekarze, przedsiębiorcy, rzemieślnicy, także z ludu wiejskiego, niewiasty zamężne i stanu panieńskiego. Jak potok jaki płynęli wszyscy na daleki Wschód ${ }^{59}$.

Za podjęcie walki o wolność ojczyzny przyszedł czas ponoszenia konsekwencji, ofiary, pojmowanej w kategoriach wyzwania wobec siebie i bliźnich.

\section{Pogeęianie więzi z Bogiem na zeseaniu}

Zesłańcy wiezieni byli pociągiem przez Petersburg, Moskwę do Niżnego Nowogrodu. Tam podczas postoju Józef udał się kościoła, był on jednak zamknięty. Do Kazania dopłynęli Wołgą, do Permu także przewieziono ich statkiem. W tym mieście był punkt zborny, z którego zesłańców rozsyłano po Syberii i dalekim wschodzie. Tu spotkali zesłańców z Południowej Rusi, czyli ziem ukraińskich. W Permie Józef spotkał też swojego brata Gabriela, zesłanego na Sybir za udział w powstaniu w Hory-Horkach. Pobyt w tym mieście trwał kilka dni. Zesłańcy przygotowali polową kapliczkę. Mszę św. odprawiano codziennie, była możliwość korzystania z sakramentów. Z Permu - już w kibitkach - należało pokonać jeszcze setki kilometrów. Te olbrzymie tereny „stały się nieznającym granic cmentarzem dziesiątków tysięcy ofiar, wyrzuconych $z$ łona własnego narodu" ${ }^{60}$. Kolejnym etapem był Tobolsk. Józefa nurtowało pytanie, czy zostanie skierowany do fortyfikacji twierdz, czego się bał, czy téz ruszy w dalszą podróż. Okazało się, że w twierdzach było już tylu skazańców, że zabrakło miejsc, stąd zapadła decyzja o przeznaczeniu go do zwyczajnej ciężkiej pracy ${ }^{61}$.

Zesłańców czekała długa droga do Tomska. To tam - 14 grudnia 1864 roku mógł Kalinowski uczestniczyć we Mszy św., wyspowiadać się i przyjąć Komunię św. Gdy usłyszał głos organów, „, trzeba było wypłakać się w ukryciu przez cały przeciagg

59 J. Kalinowski, Wspommienia 1835-1877, s. 90.

60 Tamże, s. 96.

61 Por. Cz. Gil, Ojciec Rafat Kalinowski (1835-1907), s. 73. 
nabożeństwa, łkania, trochę głośnego, nie można było jednak stłumić” ${ }^{62}$. Święta Bożego Narodzenia i część stycznia 1865 roku zesłańcy spędzili w Tomsku. W pierwszy dzień świąt Józef uczestniczył w sześciu Mszach św. - trzy ofiarował we własnych intencjach, a pozostałe za Kazimierza Laudyna, współbrata w wygnaniu, który się rozchorował. Każde wydarzenie z drogi na zesłanie uznawał za rodzaj wyzwania, które należy przyjmować z zawierzeniem ${ }^{63}$.

Kolejnym etapem był Irkuck, do którego dotarli przed Wielkanocą. Tu spędzili święta. Niemal wszystkich czekała dalsza droga za Bajkał, a tej Józef bardzo się obawiał. Po latach wyznał, że „ta dalsza droga na wschód wydawała mi się prawdziwym męczeństwem, szczególniej z bojaźni, iż odtąd ustaną wszellkie pomoce religijne"64. Nie wyobrażał już sobie życia bez możliwości korzystania z sakramentów. W narastaniu napięcia nie bez znaczenia pozostawał lęk, czy w trudnych warunkach fizycznych zdoła przeżyć. Można przyjąć, że w tym okresie miał już ukształtowaną, trwałą, pogłębioną relację z Bogiem. Na kilka godzin przed zaplanowanym wyjazdem uczestniczył we Mszy św., odprawionej w jednym z pomieszczeń więziennych. „Gdym odszedł od ołtarza, zalewałem się łzami i gwałtu wołałem do Pana Boga, aby mnie uratował. I o dziwo Opatrzności Bożej, Bóg ratunku nie odmówił" 65 . Zaledwie kilka chwil po Mszy powiadomiono go, że ma natychmiast stawić się przed gubernatorem. Do urzędu zawieziono go dorożką. Po krótkim czekaniu został poproszony do gabinetu. Gubernator oznajmił, że otrzymał list od jego rodziny, która zwróciła się do niego z prośbą, aby „zaopiekował się zesłańcem”. Najwyraźniej odniosło to pożądany skutek. Zapytał, jakie miejsce Kalinowski chce wybrać „za miejsce stałego pobytu". Józef wskazał Piotrowski Zakład Przemysłowy Żelaza. Gubernator odrzekł, że nie jest to dobry pomysł, i poradził Usole, gdyż tam „znajdzie dobre towarzystwo”.

Przeznaczenie mnie do Usola - zapisze po latach - uważam za jedną z tych chwil, które stanowią o przyszłości człowieka w tej pielgrzymce ziemskiej. Była to łaska miłosierdzia Bożego, którą po Bogu muszę zawdzięczać tym, przez których ona mi zjednaną została ${ }^{66}$.

Z całą mocą podkreśli, że poznawał wówczas „potęgę modlitwy”. W tym stwierdzeniu daje wyraz swojemu pełnemu zawierzeniu Stwórcy. W tych chwilach potwierdzał jedynie to, co wcześniej przyjął za rację ostateczną.

62 J. KALINOWsKI, Wspomnienia $1835-1877$, s. 100.

63 Stanisław Fudala zaznaczył: „Dla Kalinowskiego katorżnicza droga do miejsca przeznaczenia była czasem nieustannych moralnych wyzwań, okazją do głębszego wniknięcia w przestrzeń wiary, nadziei i miłości oraz ich praktykowania. Każde wydarzenie postrzegał jako wolę Bożą". S. FuDAlA, Ze świętym Rafatem Kalinowskim na ścieżkach wiary, nadziei i mitości, s. 48.

65 Tamże; por. Cz. GIL, Ojciec Rafat Kalinowski (1835-1907), s. 81.

66 J. KalinowskI, Wspommienia 1835-1877, s. 105. 
Kalinowski wraz z innymi skazańcami pracował w warzelni soli usytuowanej na wyspie, po której mogli swobodnie się poruszać. Zesłańcy uporządkowali wspólne życie. Wybierano starostę grupy, radnych, sędziów. Utworzono wspólną kasę, do której kierowano 10 procent otrzymywanych środków. Wspólna była kuchnia, prowadzona przez jednego $z$ wygnańcó $w^{67}$. Rano i wieczorem modlono się razem pod kierownictwem jednego z kapłanów. Przez pewien czas w Usolu przebywało ich pięciu, po wprowadzeniu obostrzeń księży zgrupowano w Tunce. W Usolu pozostał jedynie ks. Stulgiński ze Żmudzi i to on - potajemnie - zapewniał skazanym opiekę duszpasterską. Józef systematycznie przystępował do sakramentów świętych. Stale pogłębiał swoją wiedzę i formację religijną, sięgając po książki wielu teologów. Modlił się i modlitwy ofiarowywał Bogu ${ }^{68}$. Wspierał każdego potrzebującego. To wówczas zetknął się też z informacjami o karmelitach, wyprowadzających swój rodowód $z$ góry Karmel. Konstatował, że skoro ten zakon powstał na Wschodzie, to właśnie on powinien zjednoczyć „odpadłych do schizmy” z Kościołem. W duszy kreślił obraz nawrócenia „Moskwy”, czyli całej Rosji.

Od czerwca 1866 roku Kalinowski mógł zamieszkać na terenie miasta Usole. Przebywał w nim do lipca 1868 roku, kiedy to zwolniono go z wykonywania robót, ale musiał pozostać na wygnaniu, w granicach guberni irkuckiej. Mógł jednak wskazać nowe miejsce swojego pobytu. Wybrał Irkuck. Tu każdego dnia uczestniczył w porannej Mszy św. „z kornie schyloną głową i złożonymi rękami zatopionymi w głębokiej modlitwie" 69 . Postanowił oddać się pracy z młodzieżą, niejednokrotnie za darmo. $\dot{Z} y ł$ skromnie, niewiele wymagajac, stale otwarty na innych. Utrzymywał przyjacielskie kontakty z polskimi zesłańcami. W sierpniu 1872 roku pozwolono mu opuścić Irkuck i przenieść się do Carowa. Osiadł w Permie. W lipcu 1873 roku uzyskał zgodę na odwiedzenie rodzinnej Litwy. W lutym 1874 roku otrzymał ukaz zwalniający go $z$ zesłania, ale bez prawa powrotu w rodzinne strony.

67 „Według regulaminu samorządowego, co pewien czas przypadał na poszczególnych więźniów obowiązek zamiatania domostwa, przygotowania opału do pieca, obieranie ziemniaków i jarzyn do kuchni, noszenie wody itp.". S. ADAMCZYK, Niespokojne serce, s. 111.

68 Szczepan T. Praśkiewicz podkreśla, że modlitwa zawsze była dla Józefa Kalinowskiego wartością, a na pewno od czasu uwięzienia. Nazywa go „człowiekiem modlitwy”. Sz.T. PRAśxIEWTCz, Wierzyć i uczyć życiem, Kraków 2007, s. 18. Dawid T. Ulman zaznaczył: „Kalinowski w modlitwie i przez modlitwę odkrywał, w sposób najprostszy i najgłębszy zarazem, właściwą sobie podmiotowość. Nauczył się bezpośredniego zwracania do Boga, od którego pragnął pełniejszego zaspokojenia potrzeb życia wewnętrznego". D.T. ULman, Modlitwa u świętego Rafata Józefa Kalinowskiego, Kraków 2001, s. 13.

69 K. Сzекотошsка, Uczynny i zapobiegliwy, w: Wychwalajcie mężów sławnych, s. 72. 


\section{W POSZUKIWANIU ODPOWIEDZI: KRYZYS WIARY CZY PROCES WEWNĘTRZNEGO DOJRZEWANIA?}

Na drodze do świętości niezbędne są dwa zasadnicze warunki: miłość Boga i bliźniego. W życiu Józefa Kalinowskiego, późniejszego karmelity o. Rafała, a następnie świętego, nie było okresu, w którym zabrakłoby mu otwartości na drugiego człowieka, szczególnie potrzebującego ${ }^{70}$. W tym zakresie biografowie, badacze życia i dzieła o. Rafała są zgodni, mogą jedynie przesuwać akcenty. Tak prostej linii nie sposób wyznaczyć przy budowaniu jego relacji z Bogiem. Za bezsporne przyjąć trzeba, że więź ta nigdy nie została przezeń zerwana, choć przez dziesięć lat nie przystępował do sakramentu pokuty i pojednania, a przez to także do Komunii św. W tym okresie, pokrywającym się ze studiami i pracą zawodową, usilnie poszukiwał stałych wartości, sensu życia, ale - podkreślmy - bez negowania Boga, Kościoła, Tradycji. Już wówczas punktem odniesienia, jego racją ostateczną, pozostawał Stwórca ${ }^{71}$. Nie godził się na powierzchowne ujęcia i uproszczone wyjaśnienia danego zaistnienia, rozumienia porządku świata, struktury egzystencjalnej człowieka ${ }^{72}$. Z uwagi na wrodzoną i stale pogłębianą wrażliwość szukał swego miejsca w obliczu pojawiających się wyzwań życiowych. Zawsze postrzegał je w perspektywie poszukiwań, a one nieuchronnie

70 Szczepan T. Praśkiewicz zaznacza, że otwartość Kalinowskiego na innego człowieka prowadziła wręcz „do altruistycznej służby i pomocy bliźnim, do dzielenia się z nimi tym niewiele, co posiadał, zwłaszcza na Syberii: koszulą, porcją chleba, a gdy brakowało nawet tego, uśmiechem i dobrym słowem". Sz.T. PraśKIewICz, Charakterystyczne cechy duchowości, w: Święty Rafat Kalinowski wzorem i patronem wspótczesnego cztowieka. W stulecie śmierci św. Rafała 1907-2007, oprac. Sz.T. Praśkiewicz, Kraków 2007, s. 15. Warto tu pamiętać o próbie adopcji przez niego porzuconego dziecka spotkanego na ulicy Wilna latem 1860 roku. Por. List do Masi i Wiktora Kalinowskich, Wilno, 10 sierpnia 1860, w: Józef Kalinowski, Listy, t. I, cz. I, s. 69; S. Fudala, Religijność Józefa Kalinowskiego na tle religijności XIX-wiecznej, s. 110-111. Fudala zauważa, że za decyzją adopcji „krył się motyw głęboko religijny. Józef odnalazł Boga, którego z takim poświęceniem poszukiwał, odnalazł Go w człowieku bezbronnym i bezradnym - dziecku. Można powiedzieć, że Bóg objawił mu się w osobie dziecka". S. FudAlA, Ze świętym Rafatem Kalinowskim na ścieżkach wiary, nadziei i miłości, s. 33; Św. Rafat Kalinowski w stuzbie bliźnim. Materiały z inauguracji Stowarzyszenia Charytatywnego im. św. Rafata Kalinowskiego, Kraków, 28 listopada 1999, Kraków 1999.

71 Szczepan Maciaszek podnosi, że w okresie petersburskim u Józefa Kalinowskiego pojawiło się „duchowe zagubienie”, że w tym czasie „wiara i wyznawane wartości nie zostały zagubione całkowicie, ale zostały nieco osłabione". Jako powód podaje wpływ środowiska, w którym wielu uczestniczyło czynnie w praktykach religijnych, ale bez „właściwego rozeznania”. Sz. MACIASzEK, Rozeznanie drogi życiowej św. Rafała Kalinowskiego, w: Święty Rafał Kalinowski świadek wierności, red. S. Niziński, Poznań 2008, s. 32-33.

72 Tadeusz Żychiewicz okres petersburski Kalinowskiego podsumował: „Była w nim wielka do tych spraw [wiary -E. W.] ciekawość i jakby najgłębsze przywiązanie, tęsknota i gotowość na coś innego może, niż wileńska dziecięca wiara; a po Petersburgu ssąca pustka i czczość, całkiem świadome nienasycenie pełne oczekiwania". T. ŻYCHIEwICZ, Rafał Kalinowski, s. 29. Stanisław Fudala zwraca zaś uwagę na rolę czynnika intelektualnego na drodze jego poszukiwań, dążenia „do osobistego spotkania z Bogiem". S. FudALA, Religijność Józefa Kalinowskiego na tle religijności XIX-wiecznej, s. 126. 
stają się procesem ${ }^{73}$. Może przez brak odpowiedzi na szereg pytań podczas zajęć $\mathrm{z}$ religii, w otoczeniu, do wielu rzeczy dochodzić musiał większym wysiłkiem wnętrza, stąd taki, a nie inny proces duchowego wzrastania, dojrzewania. Dotykamy tu sfery szczególnej, indywidualnego „dorastania” w wierze, pogłębiania jej.

W kontekście powyższego należy pamiętać o tych stanowiskach w literaturze przedmiotu, które wskazują na „głęboki kryzys wiary” Kalinowskiego, czy nawet jej utratę. Czy jednak takie odczytywanie jego drogi nie jest następstwem wcześniej przyjętego założenia? Niezależnie od powodów, należy je zweryfikować. Życie sakramentalne jest wyrazem autentycznej więzi z Bogiem, ale drogi do Niego prowadzące wcale nie muszą biec w linii prostej. Wielu świętych (np. św. Augustyn czy kandydat na ołtarze Bogdan Jański) miało bez porównania bardziej zawiłe, trudne, dramatyczne wręcz życiowe ścieżki. Czyż dojrzałość osiaggana po okresach wewnętrznych zmagań nie jest osadzona na solidniejszych fundamentach? Oczywiście, w procesie badania naukowego pojawiające się zaistnienia odczytywać chcemy w pewnych określonych kategoriach, jakoś porządkować. Jest to zrozumiałe. Czy jednak życie duchowe jednostki, zwłaszcza w tej szczególnej sferze, jaka jest wiara, nie wymyka się takim kategoryzacjom, nie wymaga indywidualnego odczytania? Czyż potrzeba takiego spojrzenia nie jest oczywista w przypadku Józefa Kalinowskiego?

Nie można również nie zapytać, wychodząc zarówno z przesłanek fides, jak i ratio: Kalinowski powrócił do Boga czy - nigdy Go nie porzuciwszy - budował pełniejszą z Nim relację?74 Nawrócił się poprzez „nawrócenie powstańcze” czy może to doświadczenie jedynie przyspieszyło proces, który i tak był nieuchronny? ${ }^{75} \mathrm{Czy}$ zatem

73 Szczepan T. Praśkiewicz zaznaczył, że o. Rafał Kalinowski „całym swoim życiem dążył do świętości”. Nie wyodrębnia okresu, który nie wpisywałby się w ten proces, a pobyt w Petersburgu nazwał czasem „poszukiwań duchowych”, które przyjąć trzeba za składową duchowego dojrzewania. Por. Sz.T. PraśkIEWICz, Wprowadzenie. Spetniony sen, w: Święty Rafał Kalinowski wzorem i patronem wspótczesnego cztowieka, s. 8. Bartłomiej J. Kucharski lata studiów w Petersburgu określa z kolei mianem „czasu poszukiwań”, szukania pokoju duszy „w przystani Boźego Miłosierdzia”. B.J. KuCHarski, Wędrówka do źródeł nadziei, s. 45. Wreszcie Tymoteusz Frączek mówi o okresie „wewnętrznych zmagań”. T. FrączeK, Mój tułaczy żywot. Rzecz o św. Rafale Kalinowskim, Kraków [do użytku wewnętrznego, b.d.w.], s. 7. Anonimowy autor niewielkiego opracowania o udziale Józefa Kalinowskiego w powstaniu jego poszukiwania Boga uznaje za „odrodzenie życia wewnętrznego". K b., O. Rafat Kalinowski. Karmelita bosy (z okazji 70-tej rocznicy powstania styczniowego), Włocławek 1933, s. 9.

74 Jadwiga Stabińska w tytule pracy o św. Rafale Kalinowskim wykorzystała kategorię nawrócenia. Por. J. StabińsKa, W nawróceniu i w ciszy. Święty Rafał Kalinowski, Kraków 2001. Używa też zwrotu ,żarliwość nawrócenia”. Tamże, s. 66. W tej perspektywie patrzy na życie Józefa Kalinowskiego również Tymoteusz Frączek. Por. T. FrączeK, Sw. Rafat Kalinowski karmelita bosy w życiu i apostolstwie, Wrocław 1988, s. 64.

75 Władysław Kluz zaznaczy: „Dziesięć lat nie korzystał z łaski sakramentu pokuty. Przez te lata modlił się i to dużo, uczęszczał na Mszę św. nie tylko w niedzielę i święta, ale i częściej [ ...] czytał książki religỉne - a jednak nie mógł się w jednym przełamać - uklęknąć u konfesjonału i zacząć się spowiadać $[\ldots]$ w Petersburgu w kościele św. Stanisława ukląkł przy konfesjonale, ale niestety - był pusty. A później... tak jakoś schodziło bez spowiedzi, bez Komunii świętej. Przyzwyczaił się 
zasadnicza konkluzja podjętej refleksji nie powinna sprowadzać się do tezy, że Józef Kalinowski swojej więzi z Bogiem nigdy nie zerwał, jedynie ją osłabił, ale zachował przy tym pragnienie i wolę poszukiwania? ${ }^{76}$

Ponadto na przykładzie tej postaci powinniśmy dostrzec, jak silnym czynnikiem w budzeniu relacji z Bogiem może być potrzeba trwania narodowego, obrona narodowej tożsamości. Zasadność dostrzegania tej zależności staje się także znakiem współczesnych nam czasów.

\section{BIBLIOGRAFIA}

Bender R., Powstaniec-zakonnik. O. Rafat Kalinowski, Warszawa 1977.

Fudala S., Ze św. Rafatem Kalinowskim na ścieżkach wiary, nadziei i miłości, Kraków 2007.

GiL Cz. (red.), O. Rafał Kalinowski, karmelita bosy 1835-1907, Kraków 1983.

GiL Cz., O. Rafat Kalinowski, Kraków 1979,

GIL Cz., Św. Rafat Kalinowski (Rys biograficzny), w: Święty Rafał Kalinowski. Ksiega Pamiątkowa 1835-1907, Kraków 1993.

Gulgowski M., Jestem wtasnościa innych. Święty Rafał Kalinowski 1835-1907, Kraków 1990.

Kalinowski J., Listy, wyd. Cz. Gil, t. I, cz. I (1856-1872), Lublin 1978.

Kalinowski J., Wspomnienia 1835-1877, wyd. R. Bender, Lublin 1965.

Maziarz M. (red.), Święty Rafat Kalinowski. Życie. Proces. Cud kanonizacyjny. Modlitwy, Kraków 2010.

Niebelski E., Wilk S. (red.), Na drodze do świętości. Rafat Kalinowski, powstaniec 1863 i karmelita bosy, Lublin 2008.

Praśkiewicz Sz.T., „Maryja zawsze i we wszystkim”. Duchowość maryjna św. Rafała Kalinowskiego, Kraków 1999.

PraśkIEwicz Sz.T., Z Maryją zawsze i we wszystkim, Kraków 2007.

do tego stanu duszy. W prawdzie zazdrościł innym tego stanu szczęścia korzystania z sakramentów świętych. A jednak...". W. Kuuz, Dzień zbawienia, s. 117.

76 Michał Gulgowski petersburski okres w życiu Józefa Kalinowskiego określa mianem poszukiwań. Por. M. GuLgowski, Jestem własnością innych, s. 13. 


\author{
ABSTRACT \\ EUGENIUSZ WILKOWSKI \\ Józef Kalinowski and His Path to God: \\ the Internal Struggle and the Return to the Sacraments
}

At the time of his studies, the later saint Józef Kalinowski loosened his relationship with God. As a result, he stopped receiving sacraments. This took place when he was still a young man, pursuing answers to the basic questions regarding the human existential structure. This period was marked by seeking constant values and the meaning of life. However, Józef did not reject God, the Church, or the Christian Tradition. Even during those difficult years, God was always his anchor, his sole point of reference. Amidst his internal struggles, his relationship with God was growing and maturing. It goes without saying that the January Uprising and his exile to Siberia also left their mark on his path to God.

Słowa klucze: Józef Kalinowski, proces wewnętrznych zmagań, poszukiwanie wartości, budowanie trwałej więzi z Bogiem

Keywords: Józef Kalinowski, dealing with an internal conflict, seeking values, forming a stable bond with God 